\title{
PERAN MATA KULIAH BAHASA INGGRIS DALAM PENDIDIKAN SENI DAN KEAGAMAAN
}

\section{Desak Ketut Angraeni}

Institut Agama Hindu Negeri Tampung Penyang Palangkaraya

chandrika.saputri@gmail.com

\section{Riwayat Jurnal \\ Artikel diterima : 8 Juli 2019 \\ Artikel direvisi $\quad: 25$ Juli 2019 \\ Artikel disetujui : 1 Agustus 2019}

\begin{abstract}
Abstrak
Bahasa Inggris merupakan bahasa internasional yang sangat penting untuk dikuasai oleh setiap mahasiswa. Karena Bahasa Inggris mempunyai peranan dalam hal pembekalan ilmu pengetahuan untuk berkomunikasi secara global baik dalam pendidikan seni dan keagamaan. Mata kuliah Bahasa Inggris dalam pendidikan seni dan keagamaan sangatlah diperlukan. Karena mahasiswa mampu memahami Bahasa Inggris dasar seperti pemahaman membaca, menulis, berbicara dan mendengarkan dalam Bahasa Inggris. Mahasiswa dapat mengetahui penambahan kata dalam Bahasa Inggris sehingga mereka mampu membaca dan memahami bacaan Bahasa Inggris, menulis kalimat dalam Bahasa Inggris, mendengarkan dan berbicara dengan lawan bicara dengan menggunakan Bahasa Inggris.Pembekalan Bahasa Inggris dasar bagi mahasiswa Pendidikan Seni dan Keagamaan guna memajukan perkembangan seni budaya dan keagamaan secara global.

Kata Kunci: Mata Kuliah Bahasa Inggris, Pendidikan Seni dan Keagamaan
\end{abstract}

\section{Pendahuluan}

Pada saat ini mata kuliah Bahasa Inggris dasar memegang peranan penting dalam menambah ilmu pengetahuan pada mahasiswa. Bahasa Inggris kini telah diakui seluruh masyarakat dunia sebagai bahasa internasional yang telah menempati di berbagai bidang industri yang ada. Baik itu di bidang politik, ekonomi atau pun seni dan kegamaan.
Dengan demikian, perlu disadari pentingnya pendidikan Bahasa Inggris bagi kita, masyarakat Indonesia, untuk bekal masa depan dan karir yang akan atau pun sedang dijalani. Kini, persaingan global di Indonesia semakin ketat adanya. Dengan dipekerjakannya tenaga-tenaga kerja asing, lulusan mahasiswa pendidikan seni dan keagamaan harus berusaha lebih giat lagi agar dapat 
berkompetisi dengan para expat tersebut. Kemudian, lembaga - lembaga asing yang berinvestasi di Indonesia semakin bertambah banyak, dan tentunya mereka membuka kesempatan bekerja pula di perusahaan mereka, khususnya kepada masyarakat yang bisa berbahasa Inggris.

Perkembangan peran Bahasa Inggris pada jaman sekarang ini dengan melihat banyaknya sekolah internasional di negara kita ini bahkan di dunia sudah seharusnya kita menguasai Bahasa Inggris dasar. Apalagi dengan berkembangnya seni budaya dan keagamaan membuat banyak lembaga pemerintah atau swasta mengirimkan delegasinya untuk berpentas di acara mereka. Dengan demikian sebagai lulusan pendidikan seni dan keagamaan sudah harus wajib dapat memahami Bahasa Inggris.

\section{Pembahasan}

Indonesia merupakan negara
berkembang yang posisinya sangat
strategis dalam hal persaingan global. Hal
utama yang harus dimiliki untuk dapat
ikut bersaing dalam menghadapi
persaingan global adalah kemampuan
berbahasa asing khususnya Bahasa
Inggris. Bahasa Inggris sebagai bahasa

kedua dari bahasa utama kita yaitu Bahasa Indonesia mampu membantu kita untuk menghadapi persaingan global, terutama dalam perkembangan seni dan keagamaan.

Maka dari itu mata kuliah Bahasa Inggris di sebuah institut biasanya wajib diberikan. Terdapat dua SKS yang harus di tempuh pada mata kuliah Bahasa Inggris di semester awal perkuliahan. Bahasa Inggris adalah bahasa universal yang biasanya di gunakan di setiap negara yang bahasa ibunya berbahasa Inggris maupun tidak menggunakan Bahasa Inggris. Dengan demikian peran mata kuliah Bahasa Inggris sangat penting dan diperlukan untuk mempermudah mahasiswa dalam berkomunikasi ketika mereka berkesempatan memenuhi panggilan ke negara lain dalam mewakili negara kita Indonesia dalam bidang seni budaya dan keagamaan.

\section{A. Pemahaman Reading}

Membaca adalah suatu proses yang dilakukan serta dipergunakan oleh pembaca untuk memperoleh pesan, yang hendak disampaikan oleh penulis melalui media kata-kata/bahasa tulis (Tarigan, 1986:7). Suatu proses yang menuntut agar kelompok kata yang merupakan suatu 
kesatuan akan terlihat dalam suatu pandangan sekilas, dan agar makna katakata secara individual akan dapat diketahui. Kalau hal ini tidak terpenuhi, maka pesan yang tersurat dan yang tersirat tidak akan tertangkap atau dipahami, dan proses membaca itu tidak terlaksana dengan baik (Hodgson dalam Tarigan, 1986:7).

Membaca merupakan kegiatan merespons lambang-lambang tertulis dengan menggunakan pengertian yang tepat (Ahmad S. Harjasujana dalam St.Y. Slamet, 2008:67). Hal tersebut berarti bahwa membaca memberikan respons terhadap segala ungkapan penulis sehingga mampu memahami materi bacaan dengan baik. Sumber yang lain juga mengungkapkan bahwa membaca merupakan perbuatan yang dilakukan berdasarkan kerja sama beberapa keterampilan, yakni mengamati, memahami, dan memikirkan (Jazir Burhan dalam St.Y. Slamet, 2008:67).

Dapat dikatakan bahwa "reading" adalah "bringing meaning to and getting meaning from printed or written material", memetik serta memahami arti atau makna yang terkandung di dalam bahan tertulis (Finochiaro and Bonomo dalam H.G. Tarigan, 1986:8). Kegiatan membaca merupakan penangkapan dan pemahaman ide, aktivitas pembaca yang diiringi curahan jiwa dalam menghayati naskah. Proses membaca diawali dari aktivitas yang bersifat mekanis yakni aktivitas indera mata bagi yang normal, alat peraba bagi yang tuna netra. Setelah proses tersebut berlangsung, maka nalar dan institusi yang bekerja, berupa proses pemahaman dan penghayatan. Selain itu aktivitas membaca juga mementingkan ketepatan dan kecepatan juga pola kompetensi atau kemampuan bahasa, kecerdasan tertentu dan referen kehidupan yang luas. Hakikat atau esensi membaca adalah pemahaman (St.Y. Slamet, 2008:68).

Membaca hendaknya mempunyai tujuan, karena seseorang yang membaca dengan suatu tujuan, cenderung lebih memahami dibandingkan dengan orang yang tidak mempunyai tujuan (Farida Rahim, 2007:11). Tujuan utama dalam membaca adalah untuk mencari serta memperoleh informasi, mencakup isi, memahami makna bacaan (H.G. Tarigan, 1986:9).

Membaca merupakan suatu keterampilan yang kompleks yang 
melibatkan serangkaian keterampilan yang lebih kecil lainnya. Agar seseorang mampu mencapai suatu tingkat pemahaman, seharusnyalah ia mengalami proses yang cukup panjang. Oleh karenanya, kita perlu mengenal dan menguasai beberapa aspek dalam membaca pemahaman. Aspek-aspek dalam membaca pemahaman meliputi: (a) memahami pengertian sederhana (leksikal, gramatikal, retorikal), (b) memahami signifikansi atau makna (a.l. maksud dan tujuan pengarang relevansi/keadaan kebudayaan, reaksi pembaca), (c) evaluasi atau penilaian (isi, bentuk), (d) kecepatan membaca yang fleksibel, yang mudah disesuaikan dengan keadaan (Broughton [et al] dalam H.G. Tarigan, 1986:12).

Jadi dalam pemahaman membaca bacaan Bahasa Inggris, mahasiswa tidak hanya di tuntut untuk membaca bacaan berbahasa Inggris tetapi juga mampu mengerti dan memhami isi makna dari bacaan tersebut. Ada berbagai jenis bacaan yang biasanya mereka dapatkan seperti Descriptive Text, Report Text, Narative Text dan masih banyak jenis lainnya.

\section{B. Pemahaman Writing}

Menurut Gebhartd dan Dawn Rodrigues (1989: 1) writing is one of the most important things you do in college. Menulis merupakan salah satu hal yang penting kamu lakukan di perkuliahan. Menurut Pranoto (2004- 9), menulis berarti menuangkan buah pikiran ke dalam bentuk tulisan atau ungkapan atau ekspresi perasaan yang di tuangkan dalam bentuk tulisan. Barli Bram (2002: 7) berpendapat in principle, to write means to try to produce or reproduce written message. Menurutnya menulis sebagai usaha untuk membuat atau mereka ulang tulisan yang ada. Maksudnya di sini adalah, mahasiswa melakukan pemahaman membaca suatu text Bahasa Inggris terlebih dahulu, lalu mereka berusaha menceritakan kembali apa yang mereka pahami akan makna dan atai ide cerita dari bacaan tersebut.

Setiap mahasiswa tentunya memiliki pemikiran dan pemahaman masing-masing mengenai bagaimana mereka bisa menceritakan kembali bacaan tersebut. Tentunya tidak sama hasilnya pada tiap mahasiswa. Inilah yang di namakan pemahaman menulis Bahasa Inggris, walaupun maknanya pasti sama 
namun penyampaian mereka pasti berbeda beda, juga kata-katanya.

Dalam writing atau menulis Bahasa Inggris, mahasiswa membutuhkan vocabulary yang cukup banyak agar dapat menyusun tiap kata menjadi kalimat. Mahasiswa mengetahui penulisan subjeck, to-be, object dan keterangan yang dapat di sebut sebagai "grammar".

Menurut Barbara Dykes (2007: 5) dalam bukunya "Grammar for Everyone" menyebutkan bahwa pengertian paling sederhana dari grammar. Menurut dia, "grammar is a language to talk about language" atau bisa diartikan grammar adalah bahasa untuk mempelajari bahasa. Mengapa demikian? Karena dari grammar, dia lebih lanjut menjelaskan, kita bisa mempelajari bagaimana berkomunikasi dengan bahasa tidak lepas kaitanya dengan mempelajari grammar; dimulai dari kosakata dan fungsinya, pola kalimat, ungkapan, dan makananya.

Goeffrey Leech (1982: 3) dalam bukunya "English Grammar for Today" mendefiniskan grammar sebagai "Grammar refers to the mechanism according to which language works when it is used to communicate." Artinya, grammar merujuk pada mekanisme sesuai dengan kerja bahasa ketika digunakan dalam berkomunikasi. Dari pengertian tersebut bisa kita pahami bahwa grammar merupakan ilmu yang mempelajari bagaimana suatu bahasa bekerja untuk berkomunikasi.

Menurut Jeffry Coghill, Grammar of language is the set of rules that govern its structure. Grammar determines how words are arranged to form meaninful units." Artinya, grammar suatu bahasa merupakan seperangkat aturan yang mengatur struktur bahasa itusendiri. Grammar menentukan bagaimana katakata disusun untuk membentuk unit bahasa yang bermakna. Grammar disini diartikan dengan sangat jelas dimana grammar diartikan sebagai seperangkat aturan untuk membentuk bahasa agar mempunyai makna atau bisa dipahami.

Menurut Michael Swan (2005: xix) dalam bukunya "Practical English Usage", melontarkan pendapatnya mengenai definisi grammar. Menurutnya grammar adalah "The rules that show how words are combined, arranged or changed to show certain kinds of meaning." Atau bisa diartikan sebagai berikut "Grammar adalah aturan yang menerangkan bagaimana kata 
digabungkan, disusun atau diubah untuk menunjukkan beberapa jenis makna."

Aturan khusus dalam Bahasa Inggris atau di sebut juga tata bahasa memiliki tiga dasar inti dari bahasa itu sendiri, antara lain sintaks, orthographi dan etimologi. Sintaks dalam Bahasa Inggris mempelajari penyusunan katakata dalam Bahasa Inggris sehinga menjadi kalimat yang tepat sesuai kaidah tata Bahasa Inggris. Berbeda dengan orthographi yang akan lebih fokus kepada ejaan suatu bahasa yang seringkali kita temukan dalam tulisan atau lambang. Sedangkan secara etimologi yaitu ilmu yang mempelajari tentang masuknya huruf-huruf yang tepat seperti diketahui bersama "part of speech" dalam Bahasa Inggris noun (kata benda), adjective (kata sifat), verb (kata kerja), pronoun (kata ganti) , adverb (kata ketertangan), preposition (kata depan), conjunction (kata hubung) dan interjection (kata seru).

\section{Pemahaman Listening}

Listening comprehension atau pemahaman mendengarkan bertujuan mengasah kemampuan anda dalam memahami bahasa lisan yang menggunakan Bahasa Inggris. Mahasiswa di tuntut untuk harus memiliki pengetahuan struktur bahasa (grammar) Inggris yang memadai.

Pemahaman mendengarkan atau menyimak harus memahami tekanan dan nada, perbedan bunyi, idiom dalam Bahasa Inggris, ungkapan-ungkapan percakapan, kelompok atau frasa kata kerja, informasi yang tersirat (tak dinyatakan secara jelas), perbandingan dan maksa atau isi percakapan atau pembicaraan.

Menurut Anderson dan Dawson dalam Tarigan, 1987: 45, terdapat beberapa pemahaman tentang listening. Mendengarkan atau menyimak konsentratif (concentrative listening) sering juga disebut a study-type listening atau menyimak merupakan sejenis telaah. Kegiatan-kegiatan yang tercakup dalam menyimak konsentratif ini adalah mengikuti petunjuk yang terdapat dalam pembicaraan, mencari dan merasakan hubungan-hubungan seperti kelas, tempat, kualitas, waktu, urutan serta sebab akibat.

Menyimak pada concentrative listening juga mendapatkan atau memperoleh butir-butir informasi tertentu, pengertian yang mendalam, merasakan serta menghayati ide-ide sang pembicara yang tertuju pada sasaran 
maupun pengorganisasinya, memahami urutan ide-ide sang pembicara, mencari dan mencatat fakta-fakta penting.

Selain itu juga terdapat menyimak eksplorasif atau exploratory listening yang merupakan sejenis kegiatan menyimak intensif dengan maksud dan tujuan menyelidiki sesuatu lebih terarah dan lebih sempit (Tarigan 1987: 47) dalam menyimak seperti ini mahasiswa menyiagakan perhatiannya untuk menjalani serta menemukan hal-hal yang menarik sebagain informasi tambahan mengenai suatu topik

Pada saat mahasiswa menangkap bunyi bahasa, yang bersangkutan harus menggunakan kemampuan memusatkan perhatian. Bunyi yang di tangkap perlu diidentifikasi dan di telaah. Mendengarkan lawan biacara dengan berbahasa Inggris tidaklah mudah karena kita mendengarkan bahasa yang bukan bahasa utama kita sehingga di perlukan konsentrasi penuh agar tidak salah isi dan makna. Kemampuan listening dikatakan sukses jika kita mengerti apa yang di tanyakan atau bicarakan lawan bicara kepada kita dengan menggunakan Bahasa Inggris tentunya.

\section{Pemahaman Speaking}

Pemahaman speaking bisa disebut juga dengan Speaking Skill atau keterampilan berbicara. Menurut Tarigan, berbicara adalah kemampuan mengucapkan bunyi-bunyi artikulasi atau kata-kata untuk mengekspresikan menyatakan serta menyampaikan pikiran, gagasan dan perasaaan. Pengertian tersebut menunjukkan dengan jelas bahwa berbicara berkaitan dengan pengucapan kata-kata yang bertujuan untuk menyampaikan apa yang akan disampaikan baik itu perasaan, ide atu gagasan.

Menurut Brown dan Yule, berbicara adalah kemampuan mengucapkan bunyi-bunyi bahasa untuk mengekspresikan atau menyampaikan pikiran, gagasan atau perasaan secara lisan. Pengertian ini pada intinya mempunyai makna yang sama dengan pengertian yang disampaikan oleh Tarigan yaitu bahwa berbicara berkaitan dengan pengucapan kata-kata.

Menurut Haryadi dan Zamzani, secara umum, berbicara dapat diartikan sebagai suatu penyampaian maksud (ide, pikiran, isi hati) seseorang kepada orang lain dengan menggunakan bahasa lisan sehingga maksud tersebut dapat dipahami 
orang lain. Pengertian ini mempunyai makna yang sama dengan kedua pendapat yang diuraikan diatas, hanya saja diperjelas dengan tujuan yang lebih jauh lagi yaitu agar apa yang disampaikan dapat dipahami oleh orang lain.

Menurut St. Y. Slamet dan Amir, pengertian berbicara sebagai keterampilan menyampaikan pesan melalui bahasa lisan sebagai aktivitas untuk menyampaikan gagasan yang disusun serta dikembangkan sesuai dengan kebutuhan penyimak. Pengertian ini menjelaskan bahwa berbicara tidak hanya sekedar mengucapkan kata-kata, tetapi menekankan pada penyampaian gagasan yang disusun dan dikembangkan sesuai dengan kebutuhan penyimak atau penerima informasi atau gagasan.

\section{E. Pendidikan Seni dan Keagamaan}

Pendidikan Seni dan Keagamaan adalah salah satu program studi pada Fakultas Dharma Acarya di Institut Agama Hindu Negeri Tampung Penyang.

Mahasiswa Pendidikan Seni dan Keagamaan di berikan mata kuliah Bahasa Inggris pada semester ganjil dan genap. Tujuan di berikan mata kuliah Bahasa Inggris adalah agar mahasiswa mampu mengetahui pemahaman tentang
Reading, Writing, Listening dan Speaking Skill. Mereka di berikan Bahasa Inggris dasar untuk membekali mereka menghadapi tantangan global di masa depan

Seperti kita ketahui Seni Budaya dan Keagamaan Indonesia sudah mendunia, sebut saja pulau Bali yang banyak karya seni dan keagamaan yang sudah di pamerkan keluar negeri, begitu juga dengan seni dan keagamaan Kalimantan Tengah.

Seni merupakan karya yang diciptakan oleh manusia atau seniman, bisa berupa musik, seni ukir, seni tari sakral, seni suara, seni ukir dan lain-lain dan yang berhubungan dengan keagamaan adalah seni yang ada dalam ritual atau kegiatan kegamaan, misalnya ritual Tiwah yang merupakan adat Hindu kaharingan di Palangka Raya Kalimantan Tengah. Ritual Tiwah terdapat seni di dalamnya yang berupa seni musik dan seni tari dan suara.

Begitu juga dengan Seni Hindu Bali terdapat salah satunya contoh tari sakral yaitu tari Kecak. Tari Kecak adalah pertunjukan dramatari seni khas Bali yang lebih utama menceritakan mengenai Ramayana dan dimainkan 
terutama oleh laki-laki. Tarian ini dipertunjukkan oleh banyak (puluhan atau lebih) penari laki-laki yang duduk berbaris melingkar dan dengan irama tertentu menyerukan "cak" dan mengangkat kedua lengan, menggambarkan kisah Ramayana saat barisan keramembantu Rama melawan Ra hwana. Namun, Kecak berasal dari ritual sanghyang, yaitu tradisi tarian yang penarinya akan berada pada kondisi tidak sadar melakukan komunikasi dengan Tuhan atau roh para leluhur dan kemudian menyampaikan harapanharapannya kepada masyarakat.

Ketika Seni Budaya Keagamaan ini sudah mendunia dan banyak undangan dari delegasi negara di luar Indonesia maka bahasa menjadi faktor utama dalam melancarkan komunikasi antara pelaksana acara dan par undangan. Bahasa yang akan mereka gunakan secara umum adalah Bahasa Inggris, karena Bahasa Inggris adalah bahasa Internasional yang di gunakan untuk berkomunikasi antar negara.

Dengan demikian peran mata kuliah Bahasa Inggris dalam Pendidikan Seni dan Keagamaan sangatlah penting. Bagaimana mereka bisa menjelaskan arti dari tarian yang mereka bawakan jika mereka tidak mengerti atau tidak dapat berbicara Bahasa Inggris sama sekali. Memang pasti akan di sediakan penerjemah tetapi alangkah bangganya juga kita dapat menguasai bahasa asing yang utama yaitu Bahasa Inggris.

\section{Penutup}

Peran mata kuliah Bahasa Inggris dalam pendidikan seni dan kegamaan sangatlah penting dan saling berkaitan. Membaca atau Reading Comprehension, pemahaman mendengarkan atau Listening Comprehension, Speaking Comprehension atau pemahaman berbicara dan pemahaman menulis atau Writing Comprehension merupakan awal dasar memahami Bahasa Inggris sebagai bahasa asing yang sering di gunakan semua orang di dunia ini. Bayangkan ketika lulusan pendidikan seni dan keagamaan berkesempatan masuk pada rombongan delegasi pertukaran budaya ke luar negeri, tentu bekal dasar yang mereka harus kuasai adalah Bahasa Inggris. Karena Bahasa Inggris adalah bahasa internasional yang di gunakan di seluruh dunia untuk berkomunikasi antar negara agar kita sebagai pembicara atau lawan bicara mengerti dan paham apa 
yang di katakan atau yang di tanyakan atau di bahas kepada kita.

Pendidikan seni dan keagamaan memang lebih menekankan pada pelajaran seni dan agama seperti seni suara daerah, seni musik, tari sakral dan lain-lain. Namun untuk membuat seni budaya kita mendunia harus di perlukan penguasaan bahasa asing yaitu Bahasa Inggris.

Mempelajari Bahasa Inggris dapat menyenangkan bagi Mahasiswa pendidikan Seni dan Keagamaan jika disertai dengan keingintahuan yang besar dalam mengetahui bahasa asing. Walaupun ketertarikan mereka akan seni dan keagamaan sangat besar tidak ada salahnya jika disertai dengan kemampuan Bahasa Inggris yang baik. Setidaknya mereka mampu memahami dan mengerti cara membaca, menulis, mendengarkan dan berbicara Bahasa Inggris.

\section{Daftar Pustaka}

Adymifarizki.2018. Pengertian Singkat Grammar dalam Bahasa Inggris. https://adyofficial.com/pengertian -singkat-grammar-dalam-bahasainggris/.14/11/2018 (Online) diunduh:(10 Mei 2019)

Brown, H. Douglas. 2001. Teaching by Principles: An interactive approach to language pedagogy. New York: Longman.

Coghill, Jeffry. 2003. English Grammar. New York: Wiley Publishing, Inc. Dykes, Barbara. 2007. Grammar for Everyone. Victoria: ACER Press. https://id.wikipedia.org/wiki/Kecak.

(Online) diunduh:(8 Mei 2019)

Leech, Goeffry. 1982. English Grammar for Today. London: The Macmillan Press.

Michel Picard. '"Cultural Tourism' in Bali: Cultural Performances as Tourist Attraction", p.59. Author(s): Source:Indonesia, Vol. 49, (Apr., 1990), pp. 37-74. Published by: Southeast Asia Program Publications at Cornell University.

Mirnawati, Fery. 2013. Keterampilan

Berbicara (Speaking Skills). http://ferymirna.blogspot.com/201 3/12/keterampilanberbicaraspeakingskills.html.17/1 2/2013. (Online) diunduh:(8 Mei 2019)

Pelangikleang. 2010. Pengertian, Definisi, dan Fungsi Keterampilan Menyimak pada Pembelajaran Bahasa.

09/02/2010.http://kleang.blogspot. com/2010/02/pengertian-definisidan-fungsi.html. (Online) diunduh:(8 Mei 2019).

Rahim, Farida. 2007. Pengajaran Membaca di Sekolah Dasar. Jakarta: Bumi Aksara. 
St. Y. Slamet. 2008. Dasar-dasar Keterampilan Berbahasa Indonesia. Surakarta: UNS Press.

Swan, Micheal. 2005. Practical English Usage 3rd Edition. Oxford: Oxford University Press.
Tarigan, Henry Guntur, 1986. Membaca Sebagai Suatu Keterampilan Berbahasa. Bandung: Angkasa. 